Bank Asset Quality in Emerging Markets:

Determinants and Spillovers

Reinout De Bock and Alexander Demyanets 
IMF Working Paper

Monetary and Capital Markets

\title{
Bank Asset Quality in Emerging Markets: Determinants and Spillovers ${ }^{1}$ \\ Prepared by Reinout De Bock and Alexander Demyanets
}

Authorized for distribution by Peter Dattels

March 2012

\section{This Working Paper should not be reported as representing the views of the IMF.} The views expressed in this Working Paper are those of the author(s) and do not necessarily represent those of the IMF or IMF policy. Working Papers describe research in progress by the author(s) and are published to elicit comments and to further debate.

\begin{abstract}
This paper assesses the vulnerability of emerging markets and their banks to aggregate shocks. We find significant links between banks' asset quality, credit and macroeconomic aggregates. Lower economic growth, an exchange rate depreciation, weaker terms of trade and a fall in debt-creating capital inflows reduce credit growth while loan quality deteriorates. Particularly noteworthy is the sharp deterioration of balance sheets following a reversal of portfolio inflows. We also find evidence of feedback effects from the financial sector on the wider economy. GDP growth falls after shocks that drive nonperforming loans higher or generate a contraction in credit. This analysis was used in chapter 1 of the Global Financial Stability Report (September 2011) to help evaluate the sensitivity of banks' capital adequacy ratios to macroeconomic and funding cost shocks.
\end{abstract}

JEL Classification Numbers: E32, E44, E51, F30, F32, F34, G2

Keywords: Macro-financial linkages, Emerging markets, Banks, Nonperforming loans, Capital flows, Exchange rate, Terms of trade, Financial stability, Panel regressions, Time series.

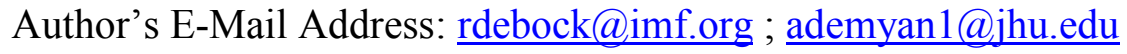

\footnotetext{
${ }^{1}$ We are grateful to Federico Boffa, Peter Dattels, José De Gregorio, Kristian Hartelius, Fuad Hasanov, Matthew Jones, Jon Huntley, Herman Kamil, Christoph Klingen, Nicolas Magud, Yan Sun, Fabian Valencia and Esteban Vesperoni for helpful comments. Alexander Demyanets thanks the IMF's Global Markets Monitoring and Analysis division for its hospitality. All errors are the sole responsibility of the authors.
} 


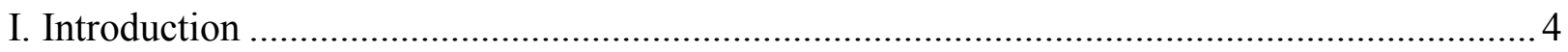

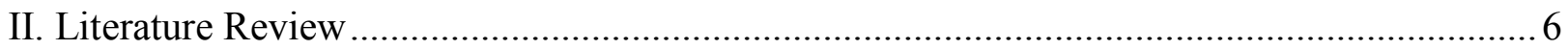

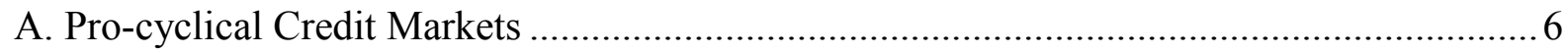

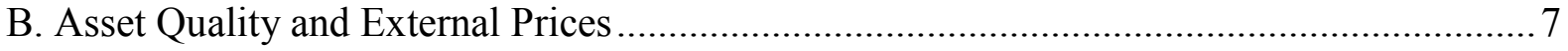

C. Asset Quality and Capital Flows ................................................................................

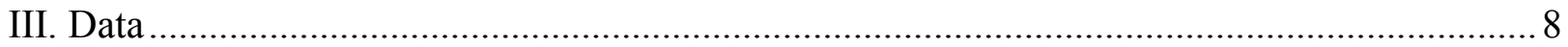

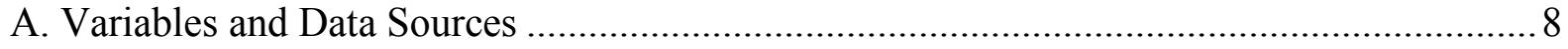

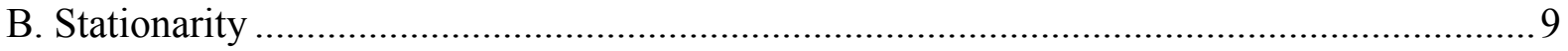

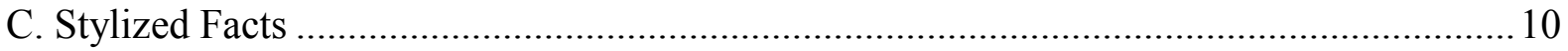

IV. Determinants of Bank Asset Quality: Panel Regressions................................................... 12

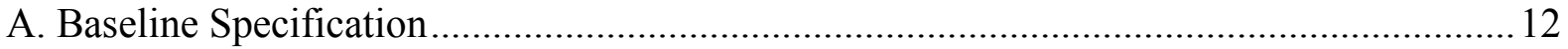

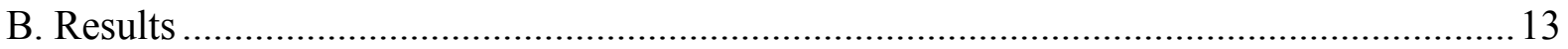

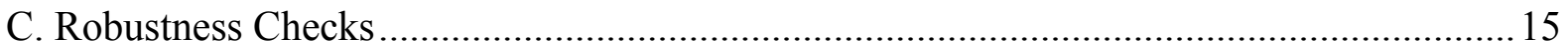

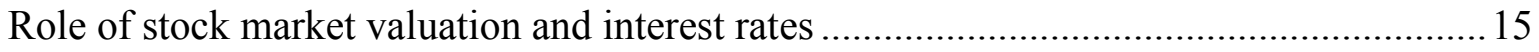

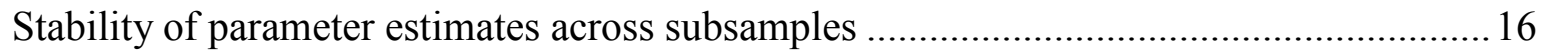

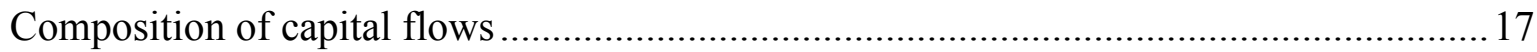

V. Modeling Feedback Loops: Structural Panel VAR ………................................................ 17

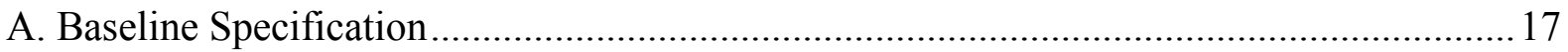

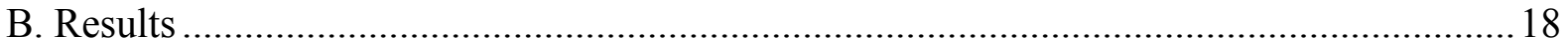

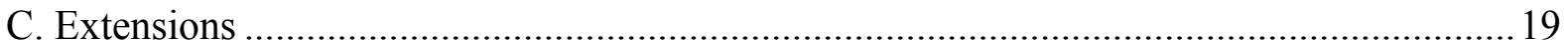

Impact on credit and asset quality of shocks to capital flows .............................................. 19

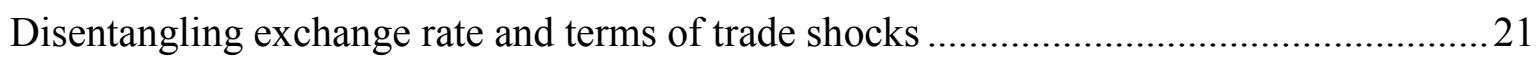

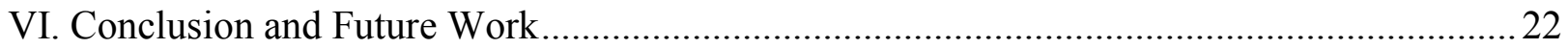

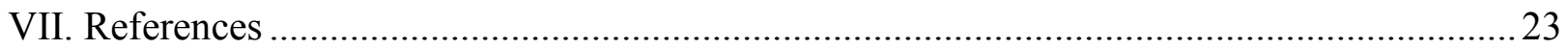

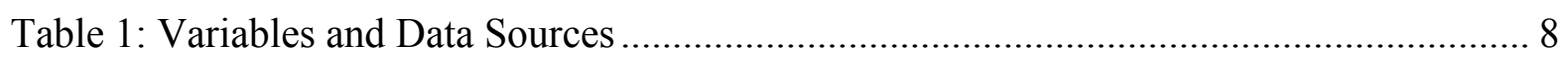

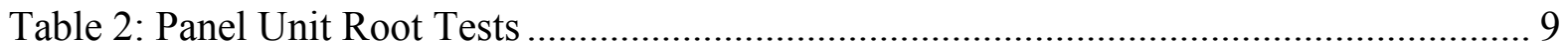

Table 3: Volatility and Correlations of Key Variables ......................................................... 10

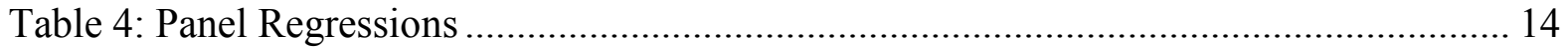

Table 5: Panel Regressions: Interest Rates and Equity Prices .................................................. 16

Table 6: Subsample Panel Regression Estimates................................................................ 17

Table 7: Panel Regressions: Capital Flows Measures ............................................................ 17

Table 8: Variance Decompositions in Baseline Model.......................................................... 19 
Figure 1: Loan Quality and Other Key Variables, 1996-2010........................................ 11

Figure 2: Growth Credit to the Private Sector in Emerging Markets, 1996-2010 ................ 11

Figure 3: Bank and Portfolio Flows to Emerging Markets, 1995-2011 ............................. 12

Figure 4: Impulse Response Functions (IRFs) of Baseline Model ................................... 18

Figure 5: IRFs of NPL due to Shocks in Different Capital Flows ...................................... 20

Figure 6: IRFs of Private Credit due to Shocks in Different Capital Flows ........................ 21

Figure 7: IRFs following Exchange Rate and Terms of Trade Shocks .............................. 22 


\section{INTRODUCTION}

An extensive literature has studied how the financial sector interacts with the real economy. ${ }^{2}$ Many models focus on information asymmetries between lenders and borrowers and operate through a balance sheet effect. An increase in asset prices pushes up the net worth of firms, households or countries, improving their capacity to borrow. Through general equilibrium effects, this dynamic can then lead to further increases in asset prices. In this way, strong balance sheets in boom periods may lead to excessive lending against inflated values of collateral. In reverse, financial intermediaries might face recapitalization needs when balance sheets deteriorate. Banks will then be less willing to extend new credit or roll over debt, and this could weigh on economic growth.

Our goal is to examine how credit growth and asset quality in emerging markets (EM) relate to different domestic and external factors. Substantial empirical work has studied feedback loops between the financial sector and the real economy. ${ }^{3}$ Despite the strong growth of EM credit in the past decade, less work has been done on the determinants of credit quality or the dynamic effect of shocks to the financial sector in EM compared to advanced economies. ${ }^{4}$ Capital flows could be especially relevant, given the substantial and time-varying external financing needs of many EM.

The contribution of this paper is twofold. First, we turn to dynamic panel regressions to determine the factors driving bank asset quality in 25 EM during 1996-2010. Second, we use structural panel Vector Auto Regressions (VARs) to quantify what happens to the real economy when credit contracts or banks' balance sheets deteriorate, measured by an increase in the ratio of aggregate nonperforming loans (NPLs) to total loans. As potential drivers of bank asset quality, we will look at a wide range of variables including GDP growth, the exchange rate, terms of trade, capital flows, equity prices and interest rates. The objective is to identify the most important ones with the help of econometrics.

The panel regressions show that a slowdown in economic growth, a weaker exchange rate or terms of trade, and rapid credit growth are independently associated with higher NPL levels. We also examine the robustness of our results to various perturbations including: incorporating additional information from financial markets and varying the subsample over which the model is estimated. We find that the market value of equity and interest rates have limited explanatory power beyond the variables specified in our baseline model. Despite the potential for structural breaks in EM, our results are quantitatively similar across subsamples,

\footnotetext{
${ }^{2}$ Some of the seminal papers are Fisher (1933), Bernanke and Gertler (1989) and Kiyotaki and Moore (1997).

${ }^{3}$ See Kaminsky and Reinhart (1999), Borio et al. (2001), Jimenez and Saurina (2006), Lown and Morgan (2006), Carlson et al. (2009), Marcucci and Quagliariello (2009), Helbling et al. (2011), and Meeks (2011) and Nkusu (2011).

${ }^{4}$ Notable exceptions are recent work on Central and Eastern Europe by Hartelius (2010) and the Gulf Cooperation Council by Espinoza and Prasad (2010)).
} 
with the notable exception of credit growth. In the earlier sample period (1996-2003), strong credit growth is more narrowly associated with asset quality problems.

The structural VAR analysis indicates the presence of significant feedback effects from the financial sector on the real economy. ${ }^{5}$ In our baseline VAR model, we only include variables that are key drivers of asset quality in the panel regressions. Given the specification of our model, we can characterize the real economy's response to developments in credit growth or asset quality. In particular, we isolate the different structural shocks in our model economy via a Choleski decomposition.

We find that economic growth falls significantly after structural shocks that drive nonperforming loans higher or generate a contraction in credit. Reassuringly, our VAR results are consistent with the evidence obtained from the panel regressions. Negative structural shocks to economic growth, the exchange rate, or debt-creating capital inflows tend to bring down private credit while loan quality deteriorates.

We show how the composition of capital flows interacts with credit growth and asset quality. Earlier literature discussed how EM are vulnerable to a sudden reversal in net capital flows, but recent work suggests that the composition of gross flows matters in a non-trivial way for economic performance or credit growth. But, not much research has been done on the relationship between different types of capital flows (such as foreign portfolio flows or Foreign Direct Investment (FDI)) and banks' asset quality.

According to our econometrics analysis, an abrupt reversal of bank-related and foreign portfolio flows would be associated with a sharp contraction of credit and a deterioration of loan quality. Specifically, a 1 percentage point decrease in portfolio and bank liabilities (\% GDP) increases the level of aggregate NPLs by 0.5 percentage points. These estimates can help to identify country-specific vulnerabilities associated with capital flows into EM in 2009-11. ${ }^{6}$ Net capital flows to EM have not been excessively strong by historical standards but portfolio and bank-related flows (rather than FDI) have dominated inflows in a number of countries. This research shows that financial conditions in these countries could worsen if these capital flows were to reverse suddenly. Our models predict that bank lending to the private sector would contract significantly. Also, the deterioration of asset quality could force some banks to recapitalize.

The paper is organized as follows. Section II sketches a framework to think about macrofinancial linkages in EM. Section III discusses the data and some stylized facts. Section IV presents panel regressions before turning to panel VARs in Section V. Section VI concludes.

\footnotetext{
${ }^{5}$ The advantage of structural VARs is that they allow us to examine the effect of a structural shock in one variable on all the other variables in the system.

${ }^{6}$ Chapter 1 of Global Financial Stability Report (2011) and chapter 4 of World Economic Outlook (2011) discuss recent trends.
} 


\section{LITERATURE REVIEW}

In this section we briefly review previous work on the interaction between asset quality, credit markets, business cycles and open economy variables such as the real exchange rate, terms of trade and capital flows. The goal is to highlight some of the earlier work that is relevant for our paper.

\section{A. Pro-cyclical Credit Markets}

A rich theoretical literature has studied spillovers from the financial system to the wider economy using models with financial imperfections. A subset of this literature focuses on the "financial accelerator" and argues that the amplification and propagation of a credit shock operates through information asymmetries between lenders and borrowers and a balance sheet effect. An increase in asset prices pushes up the net worth of firms, households or countries, and improves the capacity to borrow. Through general equilibrium effects, this dynamic then leads to further increases in asset prices. In this way, strong balance sheets in boom periods may lead to lending against inflated values of collateral. In a recent contribution that does not include a financial accelerator but focuses on EM, Mendoza (2010) studies how fluctuations in asset prices can affect the value of collateral required for international funding. Output falls when the economy becomes overleveraged and access to working capital financing is reduced.

Of course there are additional reasons why credit growth and quality are pro-cyclical aside from a financial accelerator. Herd behavior of bank managers can lead to a deterioration of credit standards during economic booms, as credit mistakes are judged more leniently if they are common to the whole industry. Institutional memory can play an important role as well, with loan officers tending to become more lenient on lending standards as the memory of previous loan busts passes.

Substantial empirical work has been done to map feedback loops between the financial system and the real economy. ${ }^{7}$ In line with the theoretical reasons described above this literature finds that credit and credit quality tends to be pro-cyclical. Turning to causality, there is considerable evidence that credit market shocks can be a driver of economic activity. Less work, however, has been done on the independent effect of credit quality on economic activity, though there is evidence that an increase in NPLs generates a strong, albeit shortlived negative response in economic activity in advanced economies, emerging markets in Central and Eastern Europe and the Gulf Cooperation Council (GCC). ${ }^{8}$

\footnotetext{
${ }^{7}$ Kaminsky and Reinhart (1999), Borio et al. (2001), Jimenez and Saurina (2006), Lown and Morgan (2006), Carlson et al. (2009), Marcucci and Quagliariello (2009), Espinoza and Prasad (2010), Hartelius (2010), Helbling et al. (2011), Meeks (2011) and Nkusu (2011).

${ }^{8}$ The key papers are Marcucci and Quagliariello (2009), Hartelius (2010), Espinoza and Prasad (2010) and Nkusu (2011).
} 


\section{B. Asset Quality and External Prices}

Several authors emphasize that a weakening local currency makes it harder to serve foreign currency debt (especially for non-tradable producers) or exacerbate weaknesses in the banking system. ${ }^{9}$ This happens because of vulnerabilities associated with an overvalued currency in a highly dollarized or lightly regulated financial system. Debt denominated in foreign currency is harder to serve when the exchange rate weakens vis-à-vis the foreign currency. ${ }^{10}$ In addition, banks do not always completely hedge the exchange rate risk that arises from currency mismatches on their balance sheet. ${ }^{11}$ Even if they would, banks might be exposed to credit risk on loans to firms that have borrowed in foreign currency and did not hedge. Note that all these channels are in contrast with older models such as the MundellFleming or sticky-price open economy models, where the financial sector is not modeled explicitly. In these models, an expansionary monetary policy and depreciation of the currency is the optimal response to an adverse external shock.

In recent years, market analysts have argued that the health of banks' balance sheets in commodity exporters is closely tied to the terms of trade. Despite a potential long-run relationship between terms of trade and exchange rates, the unconditional correlation between both variables is not always very strong, prompting many analysts and researchers to separately focus on terms of trade shocks. ${ }^{12}$ Kaminsky and Reinhart (1999) provide some evidence that up to a year prior to a banking crisis, terms-of-trade shocks tend to be positive, and the terms of trade weakens as the crisis materializes. Balance-of-payment crises are preceded, on average, by a deterioration of the terms of trade.

\section{Asset Quality and Capital Flows}

The macroeconomic implications of capital inflows and policy responses have been widely discussed, but less work has been done on the interaction between different types of gross capital flows and credit or credit quality. ${ }^{13}$ Tong and Wei (2010) is a notable exception. Using firm-level data on 3824 manufacturing firms in 24 emerging countries, they find that a

\footnotetext{
${ }^{9}$ Following is just a selection of papers on the topic; Dornbusch et al. (1995), Krugman (1999), Eichengreen and Hausman (2000), Calvo and Reinhart (2002) and Cespedes et al. (2004), Magud et al. (2011) and Kamil (2012).

${ }^{10}$ Cespedes et al. (2004), for example, propose a model where a real depreciation can have contradictory and potentially offsetting effects on firms' balance sheets.

${ }^{11}$ Burnside et al. (2001) argue that the incomplete hedge is due to the presence of implicit government bailouts.

${ }^{12}$ Looking at business cycle frequencies, Mendoza (1995) finds a mean correlation of 0.12 between the real exchange rate and terms of trade in developing countries. Cashin et al. (1995) find that the real exchange rate and the real price of commodity exports co-move in a number of commodity-exporting countries.

${ }^{13}$ Recent work has pointed out that gross capital flows are essential to fully understand the dynamics and vulnerabilities associated with a country's cross-border financing activity. See Levchenko and Mauro (2007), Cardarelli et al. (2009), Tong and Wei (2010), Borio and Diyata (2011), Pirovano et al. (2011), and Forbes and Warnock (2011).
} 
large pre-crisis exposure to non-FDI capital inflows tends to be associated with a more severe credit crunch during the crisis but that pre-crisis exposure to FDI does not worsen a credit crunch. In our paper, we answer the broader question on the vulnerabilities that capital flows can pose to an EM's financial system, while correcting for the phase of the business cycle and FX performance.

\section{DATA}

This section describes the data used in our analysis (Table 1). We also present a range of statistical tests indicating that our key variables are stationary. We conclude with some unconditional correlations and charts.

\section{A. Variables and Data Sources}

The data set contains annual observations for 25 emerging markets from 1996 to 2010 where available. The countries included in the sample are: Argentina, Brazil, Bulgaria, Chile, China, Colombia, Dominican Republic, Hungary, India, Indonesia, Israel, Korea, Malaysia, Mexico, Peru, Philippines, Poland, Romania, Russia, South Africa, Thailand, Turkey, Ukraine, Uruguay, and Venezuela.

The NPL ratio (the share of nonperforming loans as a share of total loans) is collected from Bankscope. Bankscope has the advantage that it allows us to build the data base over a longer sample than if we had used the NPL data available from the Financial Soundness Indicators (FSI) collected by the IMF's statistics department. Reassuringly, our NPL series are highly correlated with the FSI data ("Deposit Takers: Nonperforming loans as percent of total gross loans") where there is overlap.

Table 1: Variables and Data Sources

\begin{tabular}{lll}
\hline Variable & Description & Source \\
\hline $\begin{array}{l}\text { nplrat } \\
\text { rgdpgr } \\
\text { pvtratgr }\end{array}$ & Non-performing loans (share total loans) & Bankscope \\
& Growth rate of real GDP & World Economic Outlook \\
pbf & Foreign portfolio and bank flows (\% GDP) & IFS, World Economic Outlook \\
ncf & Net capital flows (\% GDP) & IFS, World Economic Outlook \\
pf & Foreign portfolio flows (\% GDP) & IFS, World Economic Outlook \\
fdi & Foreign direct investment (\% GDP) & IFS, World Economic Outlook \\
ergr & Growth U.S. Dollars per national currency & World Economic Outlook \\
rergr & Growth in the real exchange rate & Information Notice System (IMF) \\
totgr & Growth in terms of trade (goods) & World Economic Outlook \\
\hline
\end{tabular}

GDP numbers are from the World Economic Outlook (WEO) database. The nominal exchange rate (US dollar per national currency) and terms or trade based on goods prices are from WEO. We also look at the real effective exchange rate as calculated in the IMF's Information Notice System. Private credit series are from International Financial Statistics (IFS) or country authorities (through Haver). We take a number of variables from a country's 
external financial accounts in IFS; (i) Net capital flows implied by the external financial account (not including exceptional financing), (ii) foreign direct investment, (iii) foreign portfolio inflows (debt and equities), and (iv) investment liabilities associated with foreign banks. $^{14}$

Table 1 summarizes all the variables and their data sources; nplrat $_{i, t}$ is the NPL ratio in year $t$ in country $i$, rgpdgr $_{i, t}$ is the growth rate of real GDP, pvtratgr $_{i, t}$ is the growth rate of the private credit to GDP ratio. Looking at capital flows, $p b f_{i, t}$ is portfolio and bank flows scaled by GDP, $n c f_{i, t}$ is net capital flows, $p f_{i, t}$ are foreign portfolio inflows and $f d i_{i, t}$ is foreign direct investment. $\operatorname{ergr}_{i, t}$ is the change in the nominal USD exchange rate, and $\operatorname{rergr}_{i, t}$ is the change in the real exchange rate. totgr $_{i, t}$ is the percentage change in the terms of trade. ${ }^{15}$

Table 2: Panel Unit Root Tests

\begin{tabular}{lcccc}
\hline Variables & Im-Pesaran-Shin & Levin-Lin-Chu & Fisher-ADF & Fisher-PP \\
\hline nplrat & $-3.32^{* * *}$ & $-12.38^{* * *}$ & $122.17 * * *$ & $169.62^{* * *}$ \\
rgdpgr & $-6.79 * * *$ & $-9.64^{* * *}$ & 44.42 & $168.86^{* * *}$ \\
pvtratgr & $-4.22^{* * *}$ & $-9.55^{* * *}$ & 44.73 & $229.97^{* * *}$ \\
pbf & $-4.46^{* * *}$ & $-11.10^{* * *}$ & $65.75^{*}$ & $255.17 * * *$ \\
rrgr & $-6.96^{* * *}$ & $-12.25^{* * *}$ & $103.74 * * *$ & $201.39 * * *$ \\
totgr & $-10.94^{* * *}$ & $-14.59^{* * *}$ & 56.92 & $333.20^{* * *}$ \\
\hline
\end{tabular}

Note: $* * *$ and $*$ indicates significance at 1 and 5 percent, respectively. The Bayesian information criterion (BIC) determines the number of lags in each test.

\section{B. Stationarity}

Unit root tests decisively reject the null of non-stationarity (Table 2). The null hypothesis under Levin et al. (2002) test is that all panels have the same autoregressive parameter against the alternative that all panels are stationary. ${ }^{16}$ Im et al. (2003) relax the assumption of a common autoregressive parameter and instead permit it to vary across panels. The null hypothesis for the test is that all panels have unit roots against the alternative that some panels are stationary. Surprisingly, the Fisher-ADF test does not reject the null hypothesis for real GDP growth, private credit growth and changes in the terms of trade. We assume that

\footnotetext{
${ }^{14} \mathrm{We}$ follow the definitions for the capital and financial account as described in the IMF's Balance of Payments and International Investment Position Manual. Inflows arise when external liabilities are incurred by the recipient economy (inflows with a positive sign) and external liabilities are reduced (inflows with a negative sign). Net flows are the sum of gross inflows and outflows, where outflows are recorded with a negative sign.

${ }^{15} \mathrm{We}$ look at the growth rate in the terms of trade of goods prices to focus on the effect of commodity prices. In any case, for the countries in our sample this variable is highly correlated (88\%) with the growth rate in the terms of trade of goods and services.

${ }^{16}$ Since our panels are unbalanced and Levin et al. (2002) require strongly balanced data, we restrict the sample to be of equal time length.
} 
this outcome may be due to the small size of some of our panels, leading to highly insignificant p-values. ${ }^{17}$

\section{Stylized Facts}

Cross-correlations are broadly in line with what has been found in the literature (Table 3). NPLs are countercyclical, whereas portfolio flows, exchange rates (USD per national currency or the real exchange rate) and terms of trade are procyclical. The correlation between economic growth and the growth rate of private credit as a share of GDP is positive but not significantly different from zero. Interestingly, this correlation varies quite a bit across countries. Countries such as Brazil and Turkey have a pro-cyclical financial system but this is certainly not the case across the sample. Also noteworthy is that there is a negative correlation between the growth rate of credit and loan quality, suggesting that borrowers find it easier to serve loans during credit booms. Nominal and real exchange rates are highly correlated. In what follows we will focus on the nominal exchange rate (USD per national currency), but our results do not change if we use the real exchange rate.

Table 3: Volatility and Correlations of Key Variables

\begin{tabular}{lccccccc}
\hline & nplrat & rgdpgr & pvtratgr & pbf & ergr & rergr & totg \\
\hline nplrat & $\mathbf{7 . 9 9}$ & & & & & & \\
rgdpgr & $-0.19^{* *}$ & $\mathbf{4 . 3 7}$ & & & & & \\
pvtratgr & $-0.19^{* *}$ & 0.09 & $\mathbf{1 9 . 0 8}$ & & & & \\
pbf & $-0.35^{* *}$ & $0.27^{* *}$ & $0.12^{*}$ & $\mathbf{3 . 7 8}$ & & & \\
ergr & -0.10 & $0.50^{* * *}$ & 0.05 & $0.31^{* *}$ & $\mathbf{1 4 . 7 7}$ & & \\
rergr & $-0.15^{*}$ & $0.32^{* *}$ & 0.08 & $0.21^{* *}$ & $0.56^{* * *}$ & $\mathbf{1 0 . 1 6}$ & \\
totgr & $-0.13^{*}$ & $0.14^{*}$ & 0.00 & 0.00 & 0.06 & 0.03 & $\mathbf{8 . 2 9}$ \\
\hline
\end{tabular}

Note: Standard deviation on diagonal. $* * *, * *$ and $*$ indicate that a t-test rejects the null hypothesis that a single correlation coefficient is equal to zero at 1,10 and 5 percent, respectively.

Figure 1 displays the relationship between non-performing loans and the key variables in our analysis over the sample period. To put one another into perspective, Figure 2 shows that annual growth in credit to the private sector has been strong over the past decade, both in USD amount and as a share of GDP. The chart also reveals that since the financial crisis of 2008 credit in China grew very rapidly compared to other EM. This reflects the country's policy-induced lending boom of 2009-10 and has already raised some concerns on asset quality. ${ }^{18}$ Figure 3, on the other hand, illustrates that emerging economies have received significant foreign bank-related and portfolio flows starting the early 2000s. Gross capital flows also recovered quickly after collapsing in 2008. Understanding how credit growth and

\footnotetext{
${ }^{17}$ Fisher-type tests assume individual unit root processes within panels and combine independent $\mathrm{p}$-values from individual tests to arrive at the joint test of stationarity. We run the tests with augmented Dickey-Fuller and Phillips-Perron auxiliary regressions. The null in each case is that all panels have unit roots against the alternative that at least one panel is stationary.

${ }^{18}$ See Global Financial Stability Report (2011).
} 
asset quality relate to domestic growth, capital flows and external prices is becoming increasingly more important for policymakers, as EM are playing a more prominent role in the global economy.

Figure 1: Loan Quality and Other Key Variables, 1996-2010
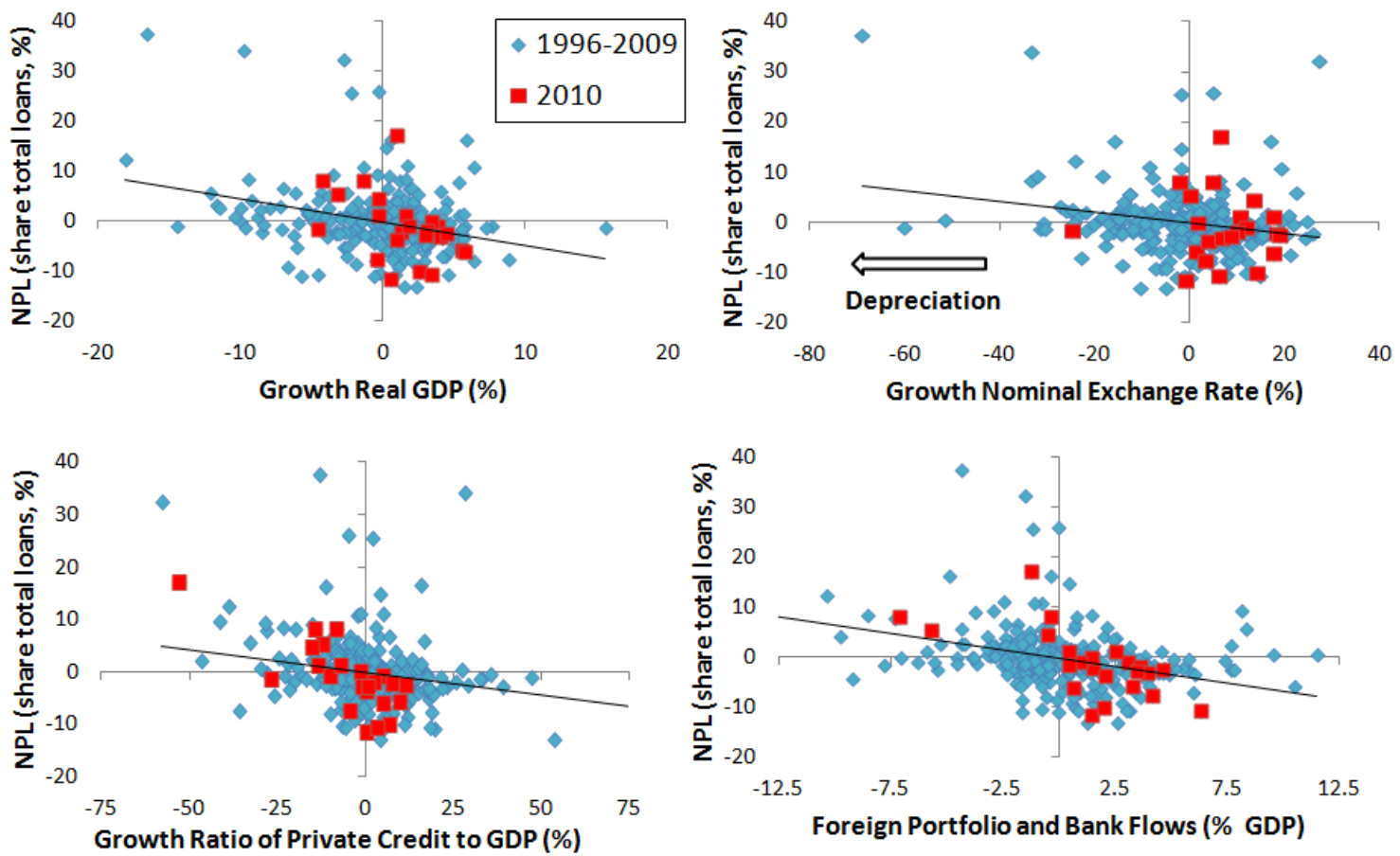

Note: Each variable has been demeaned with its country-specific sample average. Regression lines are based on 1996-2010.

Source: Bankscope, Haver, IFS, WEO, and authors' calculations.

Figure 2: Growth Credit to the Private Sector in Emerging Markets, 1996-2010

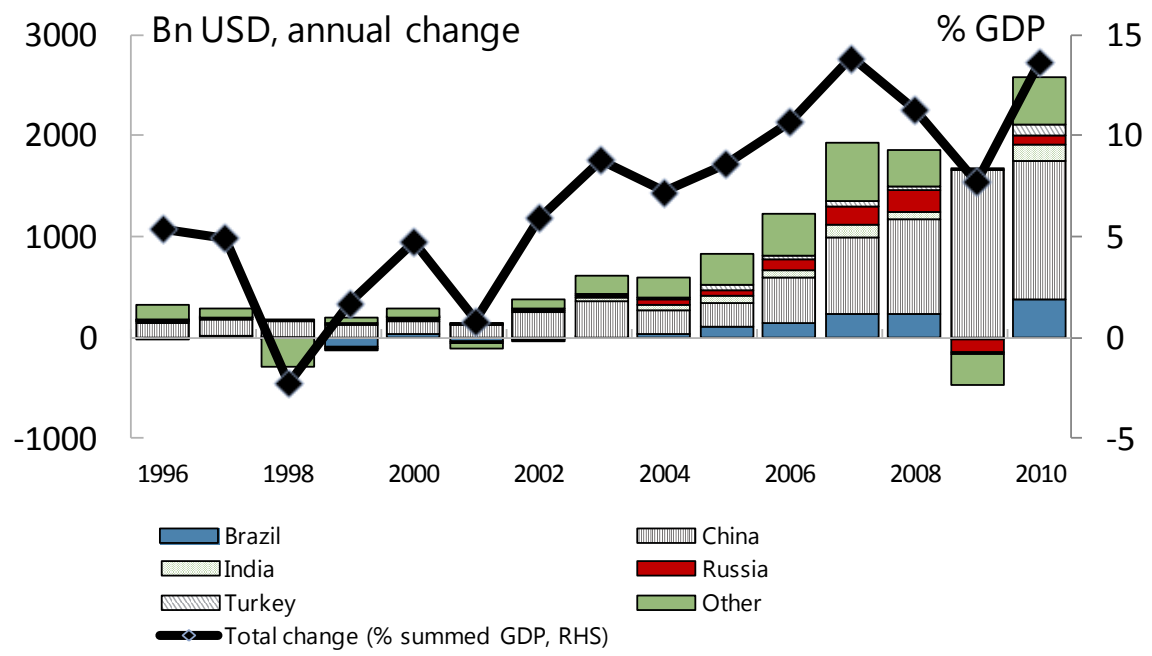

Note: Chart shows annual credit growth in 25 emerging markets.US Dollar per national currency is from WEO. Source: Haver, IFS, WEO, and authors' calculations. 
Figure 3: Bank and Portfolio Flows to Emerging Markets, 1995-2011

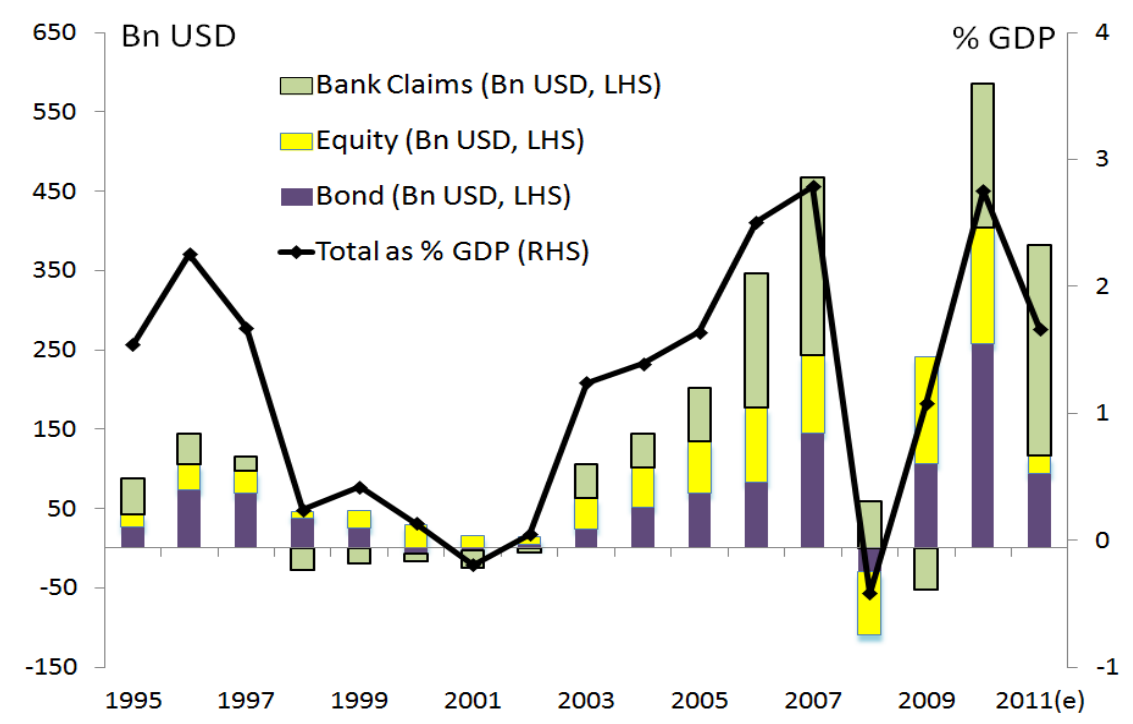

Note: Chart shows annual foreign bank-related and portfolio flows to 25 emerging markets.US Dollar per national currency is from WEO. 2011 numbers are estimates.

Source: Haver, IFS, WEO, and authors' calculations.

\section{Determinants of Bank Asset Quality: Panel Regressions}

In this section we examine the effects of macroeconomic fundamentals on bank asset quality in EM. Our proxy for asset quality is the ratio of aggregate nonperforming loans (NPLs) to total loans in the banking system.

\section{A. Baseline Specification}

We run dynamic panel regressions of the form:

$$
y_{i, t}=X_{i, t} \beta+\eta_{i, t}+\varepsilon_{i, t}
$$

where $y_{i, t}$ is the NPL ratio $n$ plrat ${ }_{i, t}, X_{i, t}$ is the vector of regressors, $\eta_{i, t}$ is the unobserved country effect, $\varepsilon_{i, t}$ is a vector of disturbances, and $\beta$ is a vector of model parameters. In order to account for omitted variables and the persistence of NPL ratio, we include lagged NPL ratio in $X_{i, t}$. We also allow for non-contemporaneous macroeconomic effects by adding lags of the macroeconomic variables.

Our approach is general-to-specific. We specify a simple model with one lag of each of the explanatory variables: ${ }^{19}$

\footnotetext{
${ }^{19}$ We restrict the specification to one lag for two reasons. First, we do not find evidence of strong macroeconomic effects on NPLs beyond one lag in bi-variate regressions. Second, we want to conserve the degrees of freedom, given the small sample size.
} 


$$
\begin{aligned}
& \text { nplrat }_{i, t}=\beta_{0}+\beta_{1} \text { rgpdgr }_{i, t}+\beta_{2} \text { rgdpgr }_{i, t-1}+\beta_{3} \text { pbf }_{i, t}+\beta_{4} \text { pbf }_{i, t-1}+\beta_{5} \text { pvtratgr }_{i, t} \\
& +\beta_{6} \text { pvtratgr }_{i, t-1}+\beta_{7} \text { totgr }_{i, t}+\beta_{7} \text { totgr }_{i, t-1}+\beta_{7} \text { ergr }_{i, t}+\beta_{8} \text { ergr }_{i, t-1}+\beta_{9} \text { nplrat }_{i, t-1} \\
& +\eta_{i, t}+\varepsilon_{i, t}
\end{aligned}
$$

where $\beta$ 's are parameters, and $i$ and $t$ denote cross-section and time indicators, respectively. We then estimate the full model and eliminate variables that are found statistically insignificant.

We consider four econometric techniques. The first two methodologies -simple OLS and country-specific fixed effects- have the advantage of well-understood asymptotic theory, but their restrictions on the correlation structure of the disturbances may not be appropriate in dynamic panel settings. A third method for estimating dynamic panels is the difference GMM method of Arellano and Bond (1991) (AB) which uses first differences and lagged series to instrument for predetermined and endogenous variables. When the series are highly autoregressive and the number of time observations is small, the Arellano-Bond estimator tends to have large finite sample bias and poor precision in simulation studies (Blundell et al., 2000). In our final method we use a system GMM method developed by Arellano and Bover (1995) and Blundell and Bond (1998) that addresses these concerns.

\section{B. Results}

Before discussing the signs on the estimate coefficients, we note that all our panel regressions yield similar quantitative and qualitative outcomes (Table 4). ${ }^{20}$ With the exception of credit growth and terms of trade, coefficients are uniformly statistically significant across the different estimation methods. The R-squares show that macroeconomic factors jointly account for a substantial fraction of variation in the aggregate NPL ratios. ${ }^{21}$

\footnotetext{
${ }^{20}$ For Arellano-Bond and Arellano-Bover-Blundell-Bond procedures, one-step estimates are reported.

${ }^{21}$ The Arellano-Bond AR(1) test for residual autocorrelation rejects the hypothesis that the errors are not autocorrelated at conventional levels. The AR(2) test does not reject the null that the errors in the level equations are not correlated.
} 
Table 4: Panel Regressions

\begin{tabular}{lcccc}
\hline variables & OLS & FE & AB & System GMM \\
\hline nplrat $_{\mathrm{t}-1}$ & $0.520^{* * *}$ & $0.384^{* * *}$ & $0.299^{* * *}$ & $0.326^{* * *}$ \\
& $(14.27)$ & $(9.21)$ & $(4.03)$ & $(6.53)$ \\
rgdpgr $_{\mathrm{t}-1}$ & $-0.162^{* *}$ & $-0.221^{* * *}$ & $-0.180^{*}$ & $-0.219^{*}$ \\
& $(-2.07)$ & $(-2.72)$ & $(-1.76)$ & $(-1.88)$ \\
pbf $_{\mathrm{t}}$ & $-0.491^{* * *}$ & $-0.543^{* * *}$ & $-0.605^{* * *}$ & $-0.670^{* * *}$ \\
& $(-6.41)$ & $(-6.97)$ & $(-6.03)$ & $(-6.72)$ \\
pvtratgr $_{\mathrm{t}-1}$ & $0.027^{*}$ & 0.02 & 0.018 & 0.025 \\
& $(1.78)$ & $(1.29)$ & $(0.98)$ & $(1.11)$ \\
totgr $_{\mathrm{t}}$ & $-0.080^{* *}$ & -0.055 & $-0.075^{* *}$ & $-0.091^{* *}$ \\
& $(-2.43)$ & $(-1.63)$ & $(-2.17)$ & $(-2.06)$ \\
ergr $_{\mathrm{t}-1}$ & $-0.047^{*}$ & $-0.055^{* *}$ & $-0.104^{* * *}$ & $-0.099^{* * *}$ \\
& $(-1.92)$ & $(-2.17)$ & $(-2.99)$ & $(-2.61)$ \\
const. & $4.508^{* * *}$ & $5.836^{* * *}$ & $6.250^{* * *}$ & $6.309^{* * *}$ \\
& $(7.36)$ & $(9.07)$ & $(4.86)$ & $(5.14)$ \\
\hline R-squared & 0.53 & 0.52 & & \\
A-B AR(1) test p-value & & 0.05 & 0.05 \\
A-B AR(2) test p-value & & 0.99 & 0.97 \\
\hline
\end{tabular}

Note: t-statistics are in parentheses. ${ }^{* * *},{ }^{* *}$, and $*$ indicates significance at 1,5 and 10 percent, respectively.

The magnitude of the coefficient on portfolio and bank flows $p b f$ is quite striking. The coefficient is highly statistically significant and economically very large: a 1 percentage point increase in this variable is associated with a reduction in the aggregate NPL ratio of approximately 0.5 percentage points. Given that it is not uncommon to see capital flows grow at double-digit speed in many emerging markets, the high sensitivity constitutes a potential source of vulnerability to a reversal of capital flows.

It is hardly surprising that economic growth is an important determinant of loan quality. NPL ratios are countercyclical, falling in business cycle upturns and rising in recessions. Interestingly, the elasticity estimate of 0.2 is comparable to what has been found for advanced economies by Nkusu (2011). Terms of trade and exchange rate appreciation, on average, have about the same independent effects. The size of the coefficients on totgr and ergr is not economically big in isolation. However, this result is consistent with Mendoza (1995) who argues that terms of trade shocks in emerging markets are a major determinant of exchange rates and the joint impact of the two compares to that of real GDP growth.

NPLs increase following rapid credit growth, but the coefficient on pvtratgr is small and insignificant. In some sense, this is a puzzling result as a body of empirical literature presents 
evidence that credit growth is a determinant of banking, currency and financial crises. ${ }^{22}$ In the next subsection we do find that the results of this literature hold in the earlier part of the sample.

\section{Robustness Checks}

We perform additional checks to determine whether a) financial variables other than those included in our specification are important, b) parameter estimates are stable within the sample period, and c) other capital flow measures are equally important.

\section{Role of stock market valuation and interest rates}

The literature suggests that asset prices and interest rates can affect bank asset quality. ${ }^{23}$ High asset prices, for instance, can cushion borrowers from unexpected shocks by facilitating access to credit and/or helping to service existing debts. Higher asset valuations should therefore be associated with lower levels of NPL ratios. Interest rate hikes, on the other hand, tend to have the opposite effects as asset prices normally decline and the cost of debt service rises, especially when loan contracts have built-in variable rates.

Asset prices and interest rates seem to contain little information beyond the information set used in our baseline regressions. To test whether asset prices and interest rates are significant determinants of NPLs, we add real equity returns reqg $r$ and lending rates $l r$ to the variables in our specification (Table 5). ${ }^{24}$ The coefficient on equity returns is zero and statistically insignificant. The coefficient on the lending rate is small, changes signs across estimation methods and is not statistically different from zero. ${ }^{25}$ The magnitudes and signs of the coefficients in our benchmark specification remain roughly unchanged.

\footnotetext{
22 In Kunt and Detragiache (1997), for instance, credit growth is quantitatively the second largest factor in explaining the probability of financial crises. Kaminsky et al. (1997) report that five out of seven studies looking at credit growth as a determinant of currency crises found statistically significant results.

${ }^{23}$ See Chen (2001), Gambacorta (2005) and Kunt and Detragiache (1997).

${ }^{24}$ Equity data (MSCI share index in local currency) is from Haver, whereas inflation numbers are from WEO. Lending rates are from IFS.

${ }^{25}$ We also ran the regressions with lending rate only. AB and System GMM methods deliver positive sign and statistical significance.
} 
Table 5: Panel Regressions: Interest Rates and Equity Prices

\begin{tabular}{|c|c|c|c|c|}
\hline variables & OLS & FE & $\mathbf{A B}$ & System GMM \\
\hline \multirow[t]{2}{*}{ nplrat $_{\mathrm{t}-1}$} & $0.543 * * *$ & $0.426 * * *$ & $0.380 * * *$ & $0.3857 * * *$ \\
\hline & $(14.05)$ & $(9.24)$ & $(9.22)$ & $(10.41)$ \\
\hline \multirow[t]{2}{*}{$\operatorname{rgdpgr}_{t-1}$} & $-0.135^{*}$ & $-0.252 * * *$ & $-0.195 * *$ & $-0.222 *$ \\
\hline & $(-1.67)$ & $(-2.88)$ & $(-2.23)$ & $(-2.87)$ \\
\hline \multirow[t]{2}{*}{$\mathrm{pbf}_{\mathrm{t}}$} & $-0.311 * * *$ & $-0.369^{* * *}$ & $-0.406^{* * *}$ & $-0.508 * * *$ \\
\hline & $(-3.26)$ & $(-3.58)$ & $(-4.24)$ & $(-5.44)$ \\
\hline \multirow[t]{2}{*}{ pvtratgr $\mathrm{t}_{\mathrm{t}-1}$} & 0.035 & 0.045 & 0.033 & 0.037 \\
\hline & $(1.43)$ & (1.6) & $(1.23)$ & (1.43) \\
\hline \multirow[t]{2}{*}{$\operatorname{totgr}_{t}$} & $-0.079 * *$ & $-0.061^{*}$ & $-0.081 * *$ & $-0.088^{* * *}$ \\
\hline & $(-2.44)$ & $(-1.78)$ & $(-2.48)$ & $(-2.68)$ \\
\hline \multirow[t]{2}{*}{$\operatorname{ergr}_{t-1}$} & $-0.100 * * *$ & $-0.101 * * *$ & $-0.132 * * *$ & $-0.143 * * *$ \\
\hline & $(-3.58)$ & $(-3.35)$ & $(-4.42)$ & $(-4.92)$ \\
\hline \multirow[t]{2}{*}{$1 r_{t}$} & -0.010 & -0.030 & 0.061 & 0.013 \\
\hline & $(-0.37)$ & $(-0.54)$ & $(1.01)$ & $(0.23)$ \\
\hline \multirow[t]{2}{*}{ reqgr $_{t}$} & 0.000 & -0.003 & 0.002 & 0.003 \\
\hline & $(0.01)$ & $(-0.45)$ & $(0.34)$ & $(0.56)$ \\
\hline \multirow[t]{2}{*}{ const. } & $3.812 * * *$ & $5.529 * * *$ & $4.209 * * *$ & $5.124 * * *$ \\
\hline & $(4.91)$ & $(5.06)$ & $(3.88)$ & $(4.96)$ \\
\hline R-squared & 0.55 & 0.54 & & \\
\hline \multicolumn{2}{|c|}{ A-B AR(1) test $p$-value } & & 0.08 & 0.06 \\
\hline \multicolumn{2}{|c|}{ A-B AR(2) test p-value } & & 0.50 & 0.47 \\
\hline
\end{tabular}

Note: t-statistics are in parentheses. ${ }^{* * *}, * *$, and $*$ indicates significance at 1,5 and 10 percent, respectively.

\section{Stability of parameter estimates across subsamples}

Parameter instability is an important issue for emerging markets as policy changes may cause structural breaks. In order to check whether the coefficients estimated in our specification are stable, we run the regressions in two sub-samples: 1996-2003 and 2004-2010. ${ }^{26}$ Table 6 shows the coefficients for the sub-samples and the full sample. With the exception of credit growth, they are quantitatively similar. The coefficient on credit growth changes signs across the sub-samples. As we discussed earlier, this could be related to the fact that there is quite a bit of cross-country variation in how credit behaves over the business cycle.

\footnotetext{
${ }^{26}$ We do not report standard errors to preserve space; most of the variables in our specification are also significant at conventional levels in the subsamples.
} 
Table 6: Subsample Panel Regression Estimates

\begin{tabular}{|c|c|c|c|c|c|c|c|c|}
\hline \multirow[b]{2}{*}{ variables } & \multicolumn{4}{|c|}{$1996: 2003$} & \multicolumn{4}{|c|}{$2004: 2010$} \\
\hline & OLS & FE & $\mathbf{A B}$ & GMM & OLS & FE & $\mathbf{A B}$ & GMM \\
\hline nplrat $t_{t-1}$ & 0.50 & 0.31 & -0.02 & 0.17 & 0.62 & 0.28 & 0.10 & 0.21 \\
\hline $\operatorname{rgdpgr}_{\mathrm{t}-1}$ & -0.08 & -0.19 & -0.21 & -0.27 & -0.21 & -0.17 & -0.12 & -0.20 \\
\hline $\mathrm{pbf}_{\mathrm{t}}$ & -0.72 & -0.69 & -0.61 & -0.72 & -0.21 & -0.35 & -0.21 & -0.30 \\
\hline pvtratgr $r_{t-1}$ & 0.03 & 0.05 & 0.02 & 0.04 & 0.01 & -0.02 & -0.06 & -0.04 \\
\hline $\operatorname{totg} r_{t}$ & -0.07 & -0.04 & -0.09 & -0.10 & 0.07 & -0.06 & -0.05 & -0.07 \\
\hline $\operatorname{rergr}_{t-1}$ & -0.05 & -0.08 & -0.10 & -0.12 & -0.03 & -0.06 & -0.01 & -0.01 \\
\hline const. & 4.75 & 6.49 & 9.58 & 7.64 & 3.55 & 5.74 & 6.39 & 6.32 \\
\hline
\end{tabular}

\begin{tabular}{cccc}
\hline \multicolumn{4}{c}{$\mathbf{1 9 9 6}: \mathbf{2 0 1 0}$} \\
\hline OLS & FE & AB & GMM \\
\hline 0.52 & 0.38 & 0.30 & 0.33 \\
-0.16 & -0.22 & -0.18 & -0.22 \\
-0.49 & -0.54 & -0.61 & -0.67 \\
0.03 & 0.02 & 0.02 & 0.03 \\
-0.08 & -0.06 & -0.08 & -0.09 \\
-0.05 & -0.06 & -0.10 & -0.10 \\
4.51 & 5.84 & 6.25 & 6.31 \\
\hline
\end{tabular}

\section{Composition of capital flows}

Given the high coefficient on portfolio and bank flows, we are interested in the behavior of different measures of capital flows. Replacing $p b f_{i, t}$ in equation 1 by other capital flow variables shows considerable dispersion in coefficients. Portfolio and bank flows have the largest impact on aggregate NPL ratios. Portfolio inflows $p f$ (excluding bank flows) is numerically second. Foreign direct investment, on the other hand, is not statistically significant.

Table 7: Panel Regressions: Capital Flows Measures

\begin{tabular}{ccccc} 
& OLS & FE & AB & System GMM \\
\hline $\mathrm{pbf}_{\mathrm{t}}$ & $-0.491^{* * *}$ & $-0.543^{* * *}$ & $-0.605^{* * *}$ & $-0.670^{* * *}$ \\
& $(-6.41)$ & $(-6.97)$ & $(-6.03)$ & $(-6.72)$ \\
$\mathrm{ncf}_{\mathrm{t}}$ & -0.052 & -0.088 & $-0.176^{* *}$ & $-0.145^{*}$ \\
& $(-0.98)$ & $(-1.13)$ & $(-2.03)$ & $(-1.73)$ \\
$\mathrm{pf}_{\mathrm{t}}$ & $-0.299^{* * *}$ & $-0.385^{* * *}$ & $-0.465^{* * *}$ & $-0.621^{* * *}$ \\
& $(-2.23)$ & $(-2.67)$ & $(-3.22)$ & $(-4.36)$ \\
$\mathrm{fdi}_{\mathrm{t}}$ & -0.031 & -0.023 & -0.06 & -0.056 \\
& $(-0.54)$ & $(-0.35)$ & $(-0.83)$ & $(-0.84)$ \\
\hline
\end{tabular}

Note: $t$-statistics are in parentheses. $* * *, * *$, and * indicates significance at 1,5 and 10 percent, respectively.

\section{Modeling Feedback Loops: Structural Panel VAR}

This section turns to a fixed-effects panel VAR to model the interactions between the macroeconomic and financial variables. We lay out the econometric model before discussing the results. The section concludes with some robustness checks.

\section{A. Baseline Specification}

Our baseline VAR specification is a model with five variables: 1) the NPL ratio nplrat, 2) the growth rate in the ratio of private credit as a share of GDP pvtratgr, 3) foreign portfolio and bank flows (\% GDP) $p b f, 4)$ real GDP growth $r g d p g r$, and 5) changes in the exchange rate ergr. To summarize, the variables included in the baseline VAR for country $i$ are:

$$
Z_{i t}=\left[\text { nplrat }_{i t}, \text { pvtratgr }_{i t}, \text { pbf }_{i t}, \text { rgdpgr }_{i t}, \text { ergr }_{i t}\right]^{\prime} \text {. }
$$


The reduced-form VAR is:

$$
Z_{i t}=c_{0}+B_{1} Z_{i t-1}+f_{i}+\varepsilon_{t},
$$

where $c_{0}$ is a constant and $f_{i}$ a country fixed effect. We will look at impulse-response functions (IRFs) to analyze the reaction of a variable to the innovation in another variable. ${ }^{27}$ The actual variance-covariance matrix of the errors is not diagonal so we orthogonalize the residuals using a recursive identification strategy. The ordering of the variables in the matrix $Z_{i t}$ implies that innovations to financial variables affect the real economy within a year but not vice versa. ${ }^{28}$ Our results are not sensitive to the ordering of the macroeconomic variables.

\section{B. Results}

Before discussing the results, we note that many of the structural shocks generate impulse response functions (IRFs) that are significantly different from zero (Figure 4). The charts show responses to positive one standard deviation Choleski shocks in all the variables.

Figure 4: Impulse Response Functions (IRFs) of Baseline Model

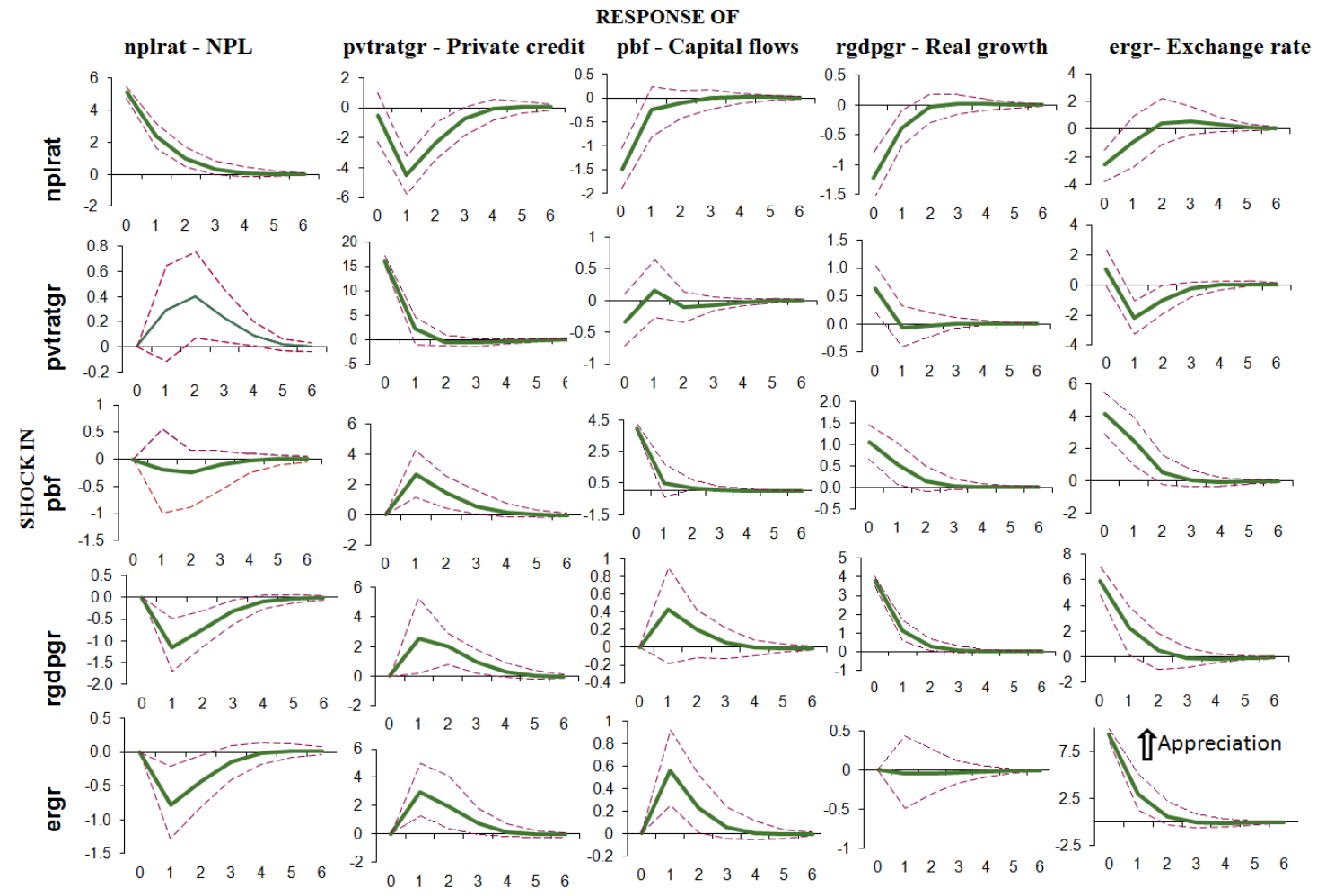

Note: Errors are $5 \%$ on each side are generated by a Monte-Carlo simulation with 200 reps.

Source: Authors' calculations.

\footnotetext{
27 The code used to estimate the model and produce impulse response functions was written by Inessa Love. Love and Zicchino (2006) describe the methodology in greater details.

${ }^{28}$ The identification scheme is close in spirit to Kaminisky and Reinhart (1999). Marcucci and Qualiariello (2008) propose a related identification scheme where they rank default rates first.
} 
Our baseline model generates clear effects of macroeconomic variables on the banking sector (Figure 4). A decrease in either economic growth, the nominal exchange rate, terms of trade or debt-creating capital inflows tends to bring down private credit while loan quality deteriorates. Turning to links between macroeconomic variables, the model is consistent with the earlier literature. For example, positive growth shocks and shocks to portfolio and bank flows tend to lead to exchange rate appreciation. ${ }^{29}$

We have focused on the role played by macroeconomic variables in explaining credit and loan quality, but Figure 4 suggests that shocks originating in the financial system also matter for the wider economy. Economic activity slows down when non-performing loans increase or credit contracts. Stress in the banking sector also leads to a depreciation of the nominal exchange rate. The effect on bank and portfolio flows is more mixed. A spike in nonperforming loans would reduce flows but this is not true for a credit shock. Finally, Table 8 shows that shocks in the financial system account for approximately 9 percent of the total forecast error variance of real growth.

Table 8: Variance Decompositions in Baseline Model

\begin{tabular}{ccccccc}
\hline \multicolumn{2}{c}{$\begin{array}{c}\text { Forecast horizon } \\
\text { (years) }\end{array}$} & $\begin{array}{c}\text { Shocks } \\
\text { nplrat }\end{array}$ & pvtratgr & pbf & rgdpgr & ergr \\
\hline nplrat & 10 & 91.07 & 0.85 & 0.28 & 5.53 & 2.27 \\
pvtratgr & 10 & 8.22 & 81.19 & 3.03 & 3.60 & 3.96 \\
pbf & 10 & 12.13 & 0.80 & 83.89 & 1.21 & 1.97 \\
rgdpgr & 10 & 8.43 & 2.06 & 7.42 & 82.07 & 0.03 \\
ergr & 10 & 4.55 & 4.02 & 13.56 & 23.27 & 54.60 \\
& & & & & & \\
nplrat & 20 & 91.07 & 0.85 & 0.28 & 5.53 & 2.27 \\
pvtratgr & 20 & 8.22 & 81.19 & 3.03 & 3.60 & 3.96 \\
pbf & 20 & 12.13 & 0.80 & 83.89 & 1.21 & 1.97 \\
rgdpgr & 20 & 8.43 & 2.06 & 7.42 & 82.07 & 0.03 \\
ergr & 20 & 4.55 & 4.02 & 13.56 & 23.27 & 54.60 \\
\hline
\end{tabular}

Note: Percent of variation of forecast error variance of the row variable explained by shocks in column variables.

Source: Authors' calculations.

\section{Extensions}

\section{Impact on credit and asset quality of shocks to capital flows}

According to the panel regressions in the previous section, portfolio flows are a key driver of the share of non-performing loans on a bank's loan book. This result holds up in the panel VAR as can be seen in Figure 5. To construct this figure we re-estimate our baseline panel VAR but replace portfolio and bank flows with other variables taken from the financial

\footnotetext{
${ }^{29}$ See Cardarelli et al. (2009) for a recent contribution.
} 
account, such as foreign portfolio flows, foreign direct investment and net capital flows. ${ }^{30}$ The variables included in the VARs are:

$$
X_{i t}=\left[\text { nplrat }_{i t}, \text { pvtratgr }_{i t}, c f_{i t}, \text { rgdpgr }_{i t}, \text { ergr }_{i t}\right]^{\prime},
$$

Where $c f$ is the capital flows variable under consideration. Figure 3 also shows that foreign portfolio flows bring down NPLs as a share of total loans. The same holds for net capital flows (this was not the case in all the panel regressions). As before, there is no significant link between foreign direct investment and loan quality.

Figure 5: IRFs of NPL due to Shocks in Different Capital Flows

(a) pbf - Portfolio and bank flows

\section{(b) pf - Foreign portfolio flows}
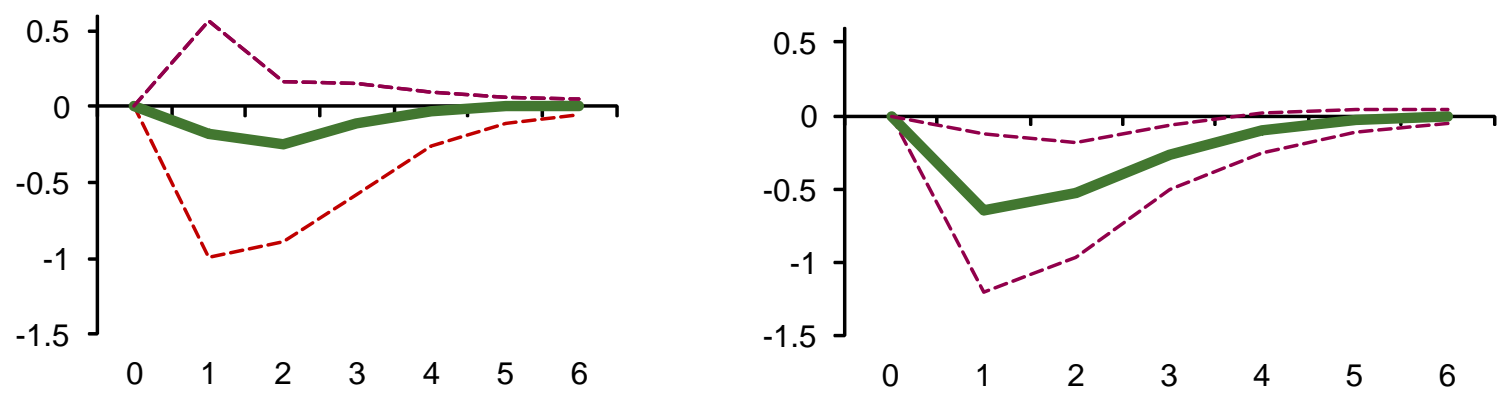

(c) fdi - Foreign direct investment

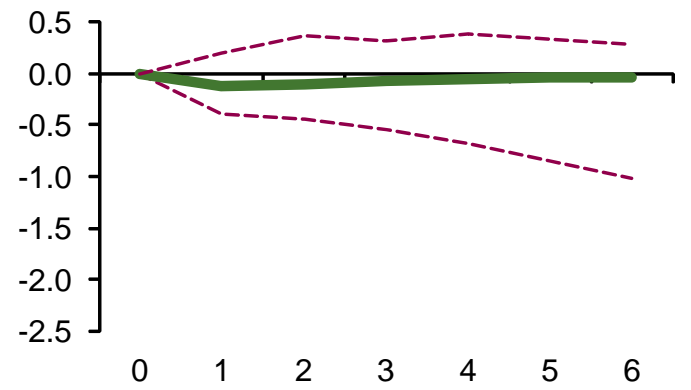

(d) ncf - Net capital flows

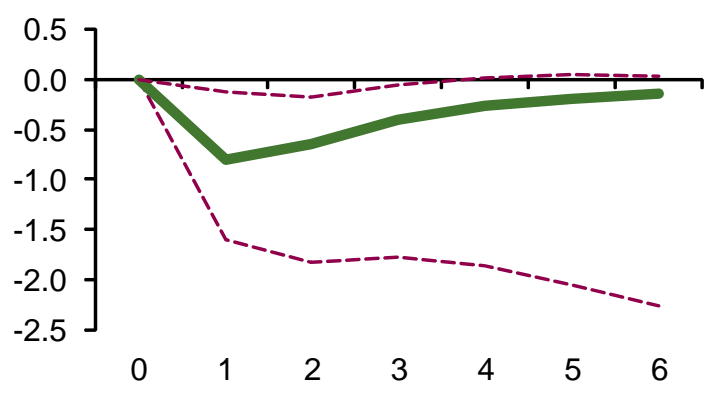

Note: Errors are 5\% on each side generated by a Monte-Carlo simulation with 200 reps.

Source: Authors' calculations.

Figure 6 demonstrates how pvtratgr, the growth rate in the ratio of private credit as a share of GDP, responds to innovations in different types of capital flows. Two findings stand out. First, innovations in debt creating portfolio flows tend to increase private credit. However, this does not hold for shocks to foreign direct investment or net capital flows. The latter result suggests that researchers should monitor gross portfolio flows more closely (rather than net flows) to better map risks to financial stability and spillovers from cross-border financial linkages.

${ }^{30}$ The IRFs for the other variables are in line with the baseline model. 
Figure 6: IRFs of Private Credit due to Shocks in Different Capital Flows

(a) pbf - Portfolio and bank flows

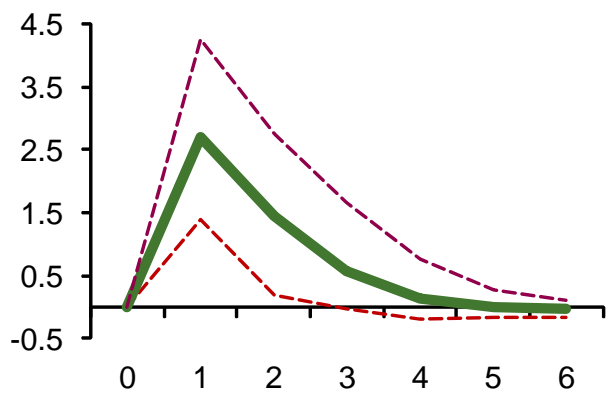

(c) fdi - Foreign direct investment

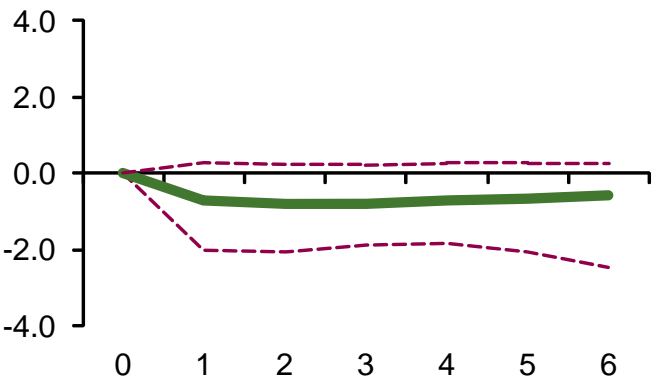

(b) pf - Foreign portfolio flows

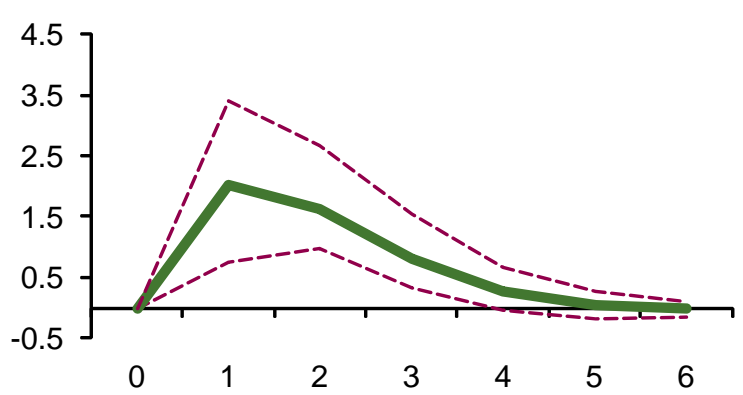

(d) ncf - Net capital flows

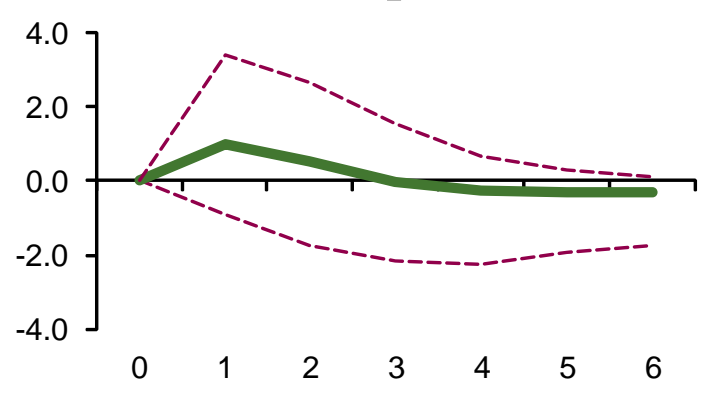

Note: Errors are 5\% on each side generated by a Monte-Carlo simulation with 200 reps.

Source: Authors' calculations.

\section{Disentangling exchange rate and terms of trade shocks}

In recent years, market analysts have argued that the health of banks' balance sheets in commodity exporters is closely related to terms of trade. The potential existence of a longrun relationship between terms of trade and exchange rates was already discussed by Keynes in his critique on the purchasing power parity theory of exchange rates. More recently, Mendoza (1995) and Cashin et al. (2004) have argued that terms of trade shocks could be an important driver of exchange rates in EM. However, simple country-level correlations of changes in both variables are often insignificant. Given the focus of our paper, this raises two questions; (i) does the financial system respond differently to a terms of trade versus exchange rate shock, and (ii) do changes in the terms of trade lead to movements in exchange rates once we correct for all the other variables in our model?

We re-estimate our baseline VAR but add the variable totgr, the growth rate of the terms of trade. The vector of variables in the system is then;

$$
Y_{i t}=\left[\text { nplrat }_{i t}, \text { pvtratgr }_{i t}, \text { pbf }_{i t}, \text { rgdpgr }_{i t}, \text { ergr }_{i t}, \text { totgr }_{i t}\right]^{\prime} .
$$

Shocks to the terms of trade or exchange rate have similar qualitative effects on the financial variables (Figure 7). Note that a shock to the terms of trade has an effect on the exchange rate but not vice versa. This result is robust to the ordering of the variables in the VAR and consistent with Mendoza (1995) and Cashin et al. (2004). 
Figure 7: IRFs following Exchange Rate and Terms of Trade Shocks

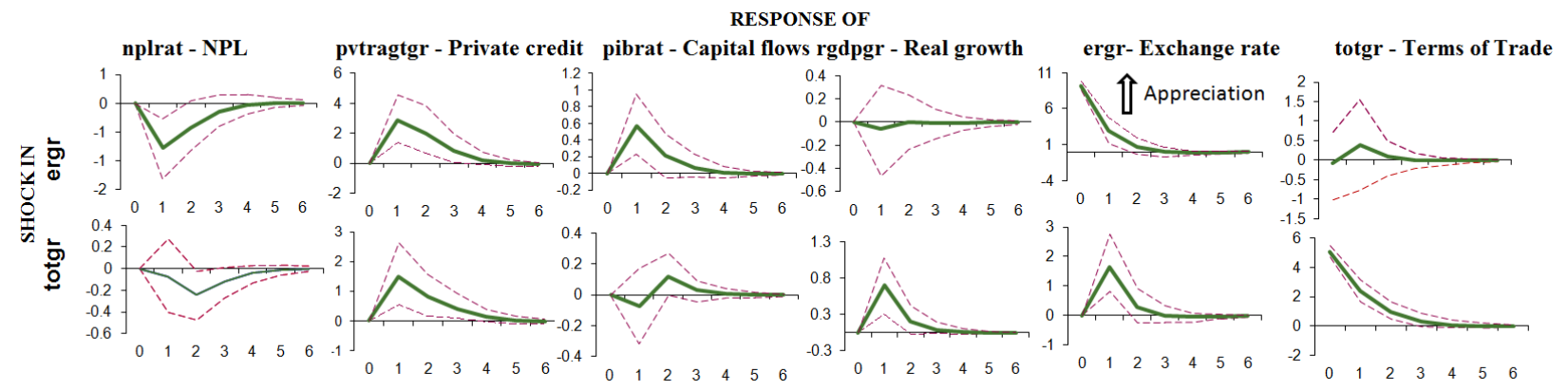

Note: Errors are 5\% on each side generated by a Monte-Carlo simulation with 200 reps.

Source: Authors' calculations.

\section{CONClusion AND Future Work}

Our models all point to significant links between macroeconomic aggregates and the financial sector. We first estimate panel regressions with non-performing loans as a dependent variable. We then look at impulse response functions in a panel VAR model that allows for feedback effects between all the variables. The analysis suggests that deteriorating growth prospects, a depreciating exchange rate, weaker terms of trade and a fall in debtcreating capital inflows will decrease private credit while loan quality worsens. We also find evidence of feedback loops from the financial sector on the wider economy. Economic activity slows down when non-performing loans increase or credit contracts while the exchange rate tends to depreciate.

The econometric links found in this paper can be used to develop scenarios for stress testing. In fact, closely related models have been used in chapter 1 of the IMF's Global Financial Stability Report (2011) to assess the vulnerability of emerging markets and their financial system to aggregate shocks. ${ }^{31}$ More concretely, we draw on a panel VAR closely related to the ones presented in this paper to calculate different scenarios with structural shocks to GDP growth, terms of trade and funding costs. In a second stage, we employ a new IMF solvency framework to assess the impact of these shocks on banks' capital adequacy ratios.

In terms of future research, three extensions come to mind. First, one can incorporate other measures of asset quality (rather than NPL numbers) in the analysis. ${ }^{32}$ Second, a more granular analysis of funding markets will improve our understanding of how financial stress is transmitted across countries. There are a number of promising avenues here such as

\footnotetext{
${ }^{31}$ De Bock and Demyanets (2011) describe this approach in greater detail.

${ }^{32}$ Heytens and Karacadag (2001) argue that the debt of companies (as a proportion of total debt) for which interest expenses exceed earnings before interest, tax, depreciation and amortization, is an excellent alternative for tracking credit quality.
} 
quantifying the vulnerabilities associated with a country's bank funding model, examining the role of the currency composition of private and public debt and measuring the implications of a changing investor base. A final extension worth exploring is the feedback channel on investment. Many EM depend on foreign investment goods for building and maintaining the domestic capital stock. ${ }^{33}$ Our panel VAR shows that worsening asset quality weighs on GDP growth and leads to a depreciation of the exchange rate. In the case of net capital good importers, a weakening currency will then push up the relative price of imported investment goods, making new orders for capital equipment more expensive in an environment of deteriorating private sector balance sheets.

\section{REFERENCES}

Arellano, M., and S. Bond (1991), "Some tests of specification for panel data: Monte Carlo evidence and an application to employment equations," Review of Economic Studies, 58, 277-297.

Arellano, M., and O. Bover (1995), "Another look at the instrumental variable estimation of error-components models," Journal of Econometrics, 68, 29-51.

Bernanke, Ben and Mark Gertler (1989), "Agency costs, net worth, and business fluctuations," American Economic Review 79, 14-31.

Berger, A., and G. Udell (2004), "The institutional memory hypothesis and the procyclicality of bank lending behavior," Journal of Financial Intermediation, 13(4), 458-95.

Blundell, R., and S. Bond (1998), "Initial conditions and moment restrictions in dynamic panel data models," Journal of Econometrics, 87, 115-143.

Blundell, R.W. and S.R. Bond and F. Windmeijer (2000), "Estimation in Dynamic Panel Data Models: Improving on the Performance of the Standard GMM estimator," in B. Baltagi (ed), Advances in Econometrics, Volume 15: Non-Stationary Panels, Panel Co-integration, and Dynamic Panels, JAI Elsevier Science.

Borio, Claudio and Piti Disyatat (2011), "Global imbalances and the financial crisis: Link or no link?," BIS working paper No 346, Basel.

Borio, Claudio, Craig Furfine, and Philip Lowe (2001). "Procyclicality of financial systems and financial stability, BIS Papers No 1, Basel.

Broner, Fernando, Tatiana Didier, Aitor Erce, and Sergio Schmukler (2011), "Gross capital flows: Dynamics and crises," mimeo, World Bank.

\footnotetext{
${ }^{33}$ See Eaton and Kortum (2001) and De Bock (2010).
} 
Burnside, Craig, Martin Eichenbaum and Sergio Rebelo (2001), "Hedging and financial fragility in fixed exchange rate regimes," European Economic Review, 45, 1151-93.

Calvo, Guillermo and Carmen Reinhart (2002), "Fear of Floating," Quarterly Journal of Economics, 117(2), 379-408.

Cardarelli, Roberto, Selim Elekdag and M. Ayhan Kose (2009), "Capital inflows: macroeconomic implications and policy responses," IMF Working Paper, 40, 2009.

Carlson, Mark, Thomas King, and Kurt Lewis (2009), "Distress in the Financial Sector and Economic Activity," Finance and Economics Discussion Series, Federal Reserve Board, Washington DC.

Cashin, Paul, Luis Céspedes, and Ratna Sahay (2004), "Commodity currencies and the real exchange rate," Journal of Development Economics, 75, 239-68.

Céspedes, Luis, Roberto Chang and Andrés Velasco (2004), "Balance Sheets and Exchange Rate Policy," American Economic Review, vol. 94(4), pages 1183-93, September.

Chen, Nan-Kuang (2001), "Bank Net Worth, Asset Prices and Economic Activity," Journal of Monetary Economics, 48, 415-436.

De Bock, Reinout (2010), “The Composition and Cyclical Behavior of Trade Flows in Emerging Economies", IMF Working Paper, 46.

De Bock, Reinout and Alexander Demyanets (2011), "Macro-financial linkages in emerging markets and impact of shocks on bank capital adequacy ratios," Global Financial Stability Report, International Monetary Fund, Washington DC, September 2011.

Demirguc-Kunt, Asli and Enrica Detragiache (1998), "The Determinants of Banking Crises in Developing and Developed Countries," IMF Staff Papers, Vol. 45.

Dornbusch, Rudiger, Ilan Goldfajn, and Rodrigo Valdes (1995), "Currency Crises and Collapses,” Brooking Papers on Economic Activity, June 1995, 219-70.

Eaton, Jonathan, and Samuel Kortum (2001), "Trade in Capital Goods", European Economic Review, 45, 1195-235.

Espinoza, Raphael, and Ananthakrishnan Prasad (2010), "Nonperforming Loans in the GCC Banking System and their Macroeconomic Effects," IMF Working Paper, 224.

Eichengreen, Barry and Ricardo Hausman (1998), "Exchange rates and financial fragility," Federal Reserve Bank of Kansas City, New Challenges for Monetary Policy.

Fisher, Irving (1933), "The debt-deflation theory of the great depression," Econometrica, 1, 337-57. 
Folkerts-Landau, David (1997), International Capital Markets: Developments, Prospects, and Key Policy Issues, International Monetary Fund, Washington, November 1997.

Forbes, Kristin and Francis Warnock (2011), “Capital flows waves; Surges, Stops, Flight and Retrenchment," mimeo, MIT.

Global Financial Stability Report (2011), Grappling with Crisis Legacies, World Economic and Financial Surveys, International Monetary Fund, Washington, September 2011.

Gambacorta, Leonardo (2005), "Inside the Bank Lending Channel," European Economic Review, 49, 1737-1759.

Hartelius (2010), “Analyzing nonperforming loans in Central and Eastern Europe based on historical experience in emerging markets," Global Financial Stability Report, Washington, April 2010.

Helbling, Thomas, Raju Huidrom, Ayhan Kose, and Christopher Otrok (2011), "Do credit shocks matter? A global perspective," European Economic Review, 55, 340-353.

Heytens, Paul and Cem Karacadag (2001), "An Attempt to Profile the Finances of China's Enterprise Sector," IMF Working Paper, 182.

Im, K. S., M. H. Pesaran, and Y. Shin (2003), "Testing for unit roots in heterogeneous panels," Journal of Econometrics, 115: 53-74.

Jiminez, Gabriel, and Jesus Saurina (2006), “Credit Cycles, Credit Risk and Prudential Regulation," International Journal of Central Banking, 2, 65-98.

Kamil, Herman (2012), “How Do Exchange Rate Regimes Affect Firms'Incentives to Hedge Currency Risk? Micro Evidence for Latin America," mimeo, International Monetary Fund.

Kiyotaki, Nobuhiro and John Moore (1997), “Credit cycles,” Journal of Political Economy 105 (2), 211-48.

Levchenko, A. and P. Mauro (2007), "Do some forms of financial flows help protect against sudden stops?," World Bank Economic Review, 21, 389-411.

Levin, A., C.-F. Lin, and C.-S. J. Chu (2002), "Unit root tests in panel data: Asymptotic and finite-sample properties," Journal of Econometrics, 108, 1-24.

Love, Inessa and Lea Zicchino (2006), "Financial development and dynamic investment behavior: Evidence from panel VAR," Quarterly Review of Economics and Finance, 46, 190-210. 
Lown, Cara and Donald Morgan (2006), "The Credit Cycle and the Business Cycle: New Findings using the Loan Officer Opinion Survey," Journal of Money, Credit and Banking, $38(6), 1575-97$.

Magud, Nicolas, Carmen Reinhart and Esteban Vesperoni (2011), "Capital Inflows, Exchange Rate Flexibility, and Credit Booms,” NBER Working Paper, 17670.

Marcucci, Juri and Mario Quagliariello (2008), "Is bank portfolio riskiness procyclical? Evidence from Italy using a vector autorgression," Journal of International Financial Markets, Institutions and Money, 18, 46-63.

Meeks, Roland (2011), "Do credit market shocks drive output fluctuations? Evidence from corporate spreads and defaults," mimeo, Bank of England.

Mendoza, Enrique (1995), "The Terms of trade, the real exchange rate, and economic fluctuations," International Economic Review, 36 (1), 101-37.

Mendoza, Enrique (2010), "Sudden stops, financial crises, and leverage," American Economic Review, 100, 1941-66.

Nkusu, Mwanza (2011), "Nonperforming Loans and Macrofinancial Vulnerabilities in Advanced Economies," IMF Working Paper, 161, July 2011.

Pirovano, Mara, Jacques Vanneste, and André Van Poeck (2011), "Portfolio and Short-term Capital Inflows to the New and Potential EU Countries: Patterns and Determinants" in W.Meeusen (ed.), The Economic Crisis and European Integration, Edward Elgar, 2011.

Rajan (1994), "Why Bank Credit Policies Fluctuate: A Theory and Some Evidence," Quarterly Journal of Economics, 109 (2), 399-441.

Tong, Hui and Shang-Jin Wei (2010), “The Composition Matters: Capital Inflows and Liquidity Crunch During a Global Economic Crisis," Review of Financial Studies, 24(6).

World Economic Outlook (2011), Tensions from the Two-Speed Recovery: Unemployment, Commodities, and Capital Flows, World Economic and Financial Surveys, International Monetary Fund, Washington, April 2011. 